\title{
Sistem Penyimpanan Obat di Apotek Kimia Farma GKB
}

\section{(Drug Storage System at Kimia Farma Pharmacy GKB)}

\author{
Ade Seldiano* Diah Ratnasari, Pemta Tiadeka \\ Prodi DIII Farmasi Fakultas Kesehatan Universitas Muhammadiyah Gresik \\ Email : adeseldiantosp@gmail.com*
}

Info artikel:

Diterima:

20/04/21

Direview:

08/05/21

Diterbitkan:

$07 / 06 / 21$

\begin{abstract}
Abstrak
Apotek merupakan salah satu tempat pelayanan bidang kesehatan di Indonesia khususnya dalam melakukan praktik kefarmasian. Penyimpanan obat merupakan suatu kegiatan perawatan serta menyimpan dengan meletakkan obat yang diterima pada tempat yang aman. Penyimpanan yang baik dapat menjadi faktor penentu mutu obat. Tujuan penelitian ini adalah untuk mengamati proses evaluasi dari sistem penyimpanan obat di Apotek Kimia Farma GKB berdasarkan Peraturan Menteri Kesehatan Republik Indonesia Nomor 73 Tahun 2016. Penelitian ini merupakan jenis penelitian observasional yang bersifat deskriptif. Pengumpulan data dilakukan dengan observasi langsung pada sistem penyimpanan obat dengan menggunakan lembar observasi dan in-depth interview dengan Apoteker. Berdasarkan pada observasi yang dilakukan, dijumpai bahwa persentase dari implementasi penyimpanan obat di Apotek Kimia Farma GKB yang berada di dalam rentang "Sangat Baik" (81$100 \%$ ) adalah 100\%. Hal ini menunjukkan bahwa Apotek Kimia Farma GKB telah memenuhi standar penyimpanan berdasarkan Permenkes Nomor 73 Tahun 2016 tentang Standar Pelayanan Kefarmasian di Apotek.

Kata kunci: evaluasi, penyimpanan obat, apotek
\end{abstract}

\begin{abstract}
Pharmacy is one of the health services in Indonesia, especially in pharmacy practice. Drug storage is a maintenance activity as well as storing the drug by placing the received item in a safe place. Good storage practice may play a role as a determining factor in assuring the drug quality. The purpose of this study was to observe the evaluation process of drug storage system at Kimia Farma Pharmacy GKB based on the Regulation of the Minister of Health of the Republic of Indonesia Number 73 of 2016. This study was a descriptive observational research type. Data collection was carried out by direct observation on the drug storage system using observation sheets and in-depth interview with pharmacists. Based on the observation results, it was found that the percentage of drug storage implementation at the Kimia Farma Pharmacy GKB within "Very Good" (81-100\%) rank was 100\%. Thus this study showed that the Kimia Farma P h a r m a c y GKB Pharmacy has met the storage standards based on the Regulation of the Minister of Health of the Republic of Indonesia Number 73 of 2016 concerning the Pharmaceutical Service Standards in Pharmacy.
\end{abstract}

Key words: evaluation, drug storage, pharmacy

\section{PENDAHULUAN}

Apotek merupakan salah satu tempat pelayanan bidang kesehatan di Indonesia khususnya dalam melakukan praktik kefarmasian. Dalam Permenkes Nomor 73 Tahun 2016 tentang Standar Pelayanan Kefarmasian di Apotek, pelayanan kefarmasian merupakan kegiatan penunjang kesehatan yang bertujuan untuk meningkatkan efektivitas serta efisiensi dalam penggunaan alat kesehatan dan obat-obatan. Penggunaan obat tidak bisa dipisahkan dari faktor yang mendukung kesehatan manusia (Menkes RI, 2016). Fasilitas pelaanan kesehatan yang memadai dan adanya penyediaan jumlah obat yang cukup, bermutu serta terdistribusi secara merata dengan harga yang terjangkau dapat mendukung optimalnya bentuk fasilitas pelayanan kesehatan yaitu apotek (Presiden RI, 2009) 
Pengelolaan perbekalan farmasi adalah suatu siklus kegiatan, yang terdiri atas perencanaan, pengadaan, penyimpanan, pendistribusian, pemusnahan, pencatatan dan pelaporan, serta evaluasi. Salah satu prioritas dari bagian pelayanan kefarmasian adalah pengelolaan perbekalan farmasi yang meliputi obat, bahan obat, serta alat kesehatan. Oleh karena itu penerapan praktik penyimpanan persediaan obat menjadi hal yang sangat penting guna menunjang pelayanan kefarmasian yang optimal. Salah satu aspek penting dalam siklus pengelolaan perbekalan farmasi adalah penyimpanan dengan tujuan untuk menjamin mutu sediaan yang memastikan terhindarnya perbekalan farmasi tersebut dari kerusakan fisik maupun kimia. Penyimpanan obat merupakan suatu kegiatan perawatan dengan meletakkan obat yang diterima tersebut pada tempat yang aman selama penyimpanan. Penyimpanan yang baik dapat menjadi faktor penentu mutu obat (Karlida dan Ida, 2017).

Ketersediaan perbekalan farmasi khususnya obat-obatan merupakan bagian penting dalam pelayanan kefarmasian sehingga apabila ditemukan kesalahan dalam prosedur penyimpanannya, hal ini akan berpengaruh pada kualitas pelayanan kefarmasian di apotek (Ardiningtyas dan Dwi, 2019). Penyimpanan perbekalan kefarmasian diatur dalam Permenkes RI Nomor 73 Tahun 2016. Jenis perbekalan farmasi meliputi obat dan alat kesehatan yang memiliki tampilan serta penamaan serupa (LASA $=$ Look Alike Sound Alike). Obat jenis ini tidak boleh ditempatkan berdekatan serta wajib diberi label atau penandaan khusus, sehingga kesalahan pengambilan obat tidak terjadi. Selain itu, kesalahan dalam pemberian obat dapat disebabkan oleh penataan obat yang kurang tepat, khususnya obat LASA (Asyikin, 2018). Jenis dan bentuk sediaan perlu obat disusun dengan menggunakan sistem FIFO (First In First Out) dan FEFO (First Expired First Out) untuk meminimalkan terjadinya kerusakan serta kehilangan obat. Penyimpanan obat harus disusun berdasarkan urutan alfabetis sehingga memudahkan dalam pengawasan serta pencarian jenis obat ketika dalam proses distribusi kepada pihak konsumen (Menkes RI, 2016).

Oleh karena itu, pada penelitian ini dilakukan pengamatan terhadap evaluasi sistem penyimpanan di Apotek Kimia Farma GKB Gresik dengan harapan penelitian ini dapat meningkatkan kualitas pelayanan kefarmasian di Apotek Kimia Farma GKB Gresik.

\section{METODE PENELITIAN}

Penelitian ini termasuk dalam penelitian observasional yang bersifat deskriptif dan dilakukan pada bulan Maret sampai dengan April 2020. Populasi penelitian adalah sistem penyimpanan obat di apotek, sedangkan sampel yang digunakan adalah sistem penyimpanan obat di Apotek Kimia Farma GKB. Teknik pengambilan sampel dilakukan dengan metode purposive sampling dan simple random sampling pada variabel tertentu. Pengumpulan data dilakukan dengan cara observasi langsung terhadap sistem penyimpanan obat dengan menggunakan metode check list pada lembar observasi. Persentase implementasi sistem penyimpanan obat dihitung dengan menggunakan rumus menurut Asyikin (2018), sebagai berikut:

$$
\% \text { implementasi }=\frac{\text { skor } \text { empirik }}{\text { skor } \text { ideal }} \times 100 \%
$$

Selanjutnya data yang diperoleh dianalisis 
secara deskriptif dengan pengelompokkan

berdasarkan pada nilai persentase

implementasi sistem penyimpanan obat,

terbagi menjadi lima kriteria (Asyikin, 2018),

sebagai berikut:

1. Sangat Baik : $81-100 \%$

2. Baik

$$
\text { : } 61-80 \%
$$

3. Cukup Baik : $41-60 \%$

4. Kurang Baik :21-40\%

5. Sangat Kurang : :41\%-60\%

Tabel 1. Variabel Observasi

\begin{tabular}{|c|c|c|}
\hline No. & Variabel Observasi & Persentase $(\%)$ \\
\hline 1. & $\begin{array}{l}\text { Obat/bahan obat disimpan dalam } \\
\text { wadah asli dari pabrik. }\end{array}$ & $100 \%$ \\
\hline 2. & $\begin{array}{l}\text { Ada informasi yang tertulis jelas } \\
\text { apabila dipindah kedalam wadah } \\
\text { baru (nama obat, nomor bets, } \\
\text { tanggal kadaluarsa). }\end{array}$ & $100 \%$ \\
\hline 3. & $\begin{array}{l}\text { Obat disimpan pada kondisi } \\
\text { penyimpanan yang tercantum dalam } \\
\text { kemasan. }\end{array}$ & $100 \%$ \\
\hline 4. & $\begin{array}{l}\text { Tempat penyimpanan obat tidak } \\
\text { dipergunakan untuk penyimpanan } \\
\text { barang lain. }\end{array}$ & $100 \%$ \\
\hline 5. & $\begin{array}{l}\text { Sistem penyimpanan berdasarkan } \\
\text { bentuk sediaan. }\end{array}$ & $100 \%$ \\
\hline 6. & $\begin{array}{l}\text { Sistem penyimpanan berdasarkan } \\
\text { kelas terapi. }\end{array}$ & $100 \%$ \\
\hline 7. & $\begin{array}{l}\text { Sistem penyimpanan disusun secara } \\
\text { alfabetis. }\end{array}$ & $100 \%$ \\
\hline 8. & $\begin{array}{l}\text { Pengeluaran obat memakai sistem } \\
\text { FIFO. }\end{array}$ & $100 \%$ \\
\hline 9. & $\begin{array}{l}\text { Pengeluaran obat memakai sistem } \\
\text { FEFO. }\end{array}$ & $100 \%$ \\
\hline 10. & $\begin{array}{l}\text { Ruang } \\
\text { memperhatikan kondisi sanitasi, } \\
\text { temperatur, kelembaban, adanya } \\
\text { ventilasi serta pemisahan. }\end{array}$ & $100 \%$ \\
\hline 11. & $\begin{array}{l}\text { Ruang penyimpanan dilengkapi } \\
\text { dengan rak/ lemari obat, pallet, } \\
\text { pendingin ruang (AC), lemari } \\
\text { pendingin. }\end{array}$ & $100 \%$ \\
\hline 12. & $\begin{array}{lcr}\text { Tersedianya } & \text { lemari } & \text { khusus } \\
\text { penyimpanan } & \text { narkotika } & \text { dan } \\
\text { psikotropika. } & & \end{array}$ & $100 \%$ \\
\hline 13. & $\begin{array}{l}\text { Tersedianya kartu stok obat pada } \\
\text { setiap obat dalam rak/lemari } \\
\text { penyimpanan. }\end{array}$ & $100 \%$ \\
\hline 14. & $\begin{array}{l}\text { Tersedianya kartu suhu dan alat } \\
\text { pengukur suhu dalam ruang } \\
\text { penyimpanan. }\end{array}$ & $100 \%$ \\
\hline 15 . & $\begin{array}{l}\text { Ruang arsip dalam penyimpanan } \\
\text { dokumen yang berkaitan dengan } \\
\text { pengelolaan sediaanfarmasi }\end{array}$ & $100 \%$ \\
\hline
\end{tabular}

III. HASIL DAN PEMBAHASAN

Hasil pengamatan sistem penyimpanan obat di Apotek Kimia Farrna GKB Gresik pada bulan Maret-April 2020 ditunjukkan oleh Tabel 2

Tabel 2. Hasil Pengamatan Sistem Penyimpanan Obat di Apotek Kimia Farma GKB

\begin{tabular}{|c|c|c|}
\hline No & $\begin{array}{c}\text { Variabel } \\
\text { Observasi }\end{array}$ & Persentase $(\%)$ \\
\hline 1. & $\begin{array}{l}\text { Obat/ bahan obat } \\
\text { disimpan dalam } \\
\text { wadah asli dari } \\
\text { pabrik. }\end{array}$ & $100 \%$ \\
\hline 2. & $\begin{array}{l}\text { Ada informasi } \\
\text { yang tertulis } \\
\text { jelas apabila } \\
\text { dipindah } \\
\text { kedalam wadah } \\
\text { baru (nama obat, } \\
\text { nomor bets, } \\
\text { tanggal } \\
\text { kadaluarsa). }\end{array}$ & $100 \%$ \\
\hline 3. & $\begin{array}{l}\text { Obat disimpan } \\
\text { pada kondisi } \\
\text { penyimpanan } \\
\text { yang tercantum } \\
\text { dalam kemasan. }\end{array}$ & $100 \%$ \\
\hline 4. & $\begin{array}{l}\text { Tempat } \\
\text { penyimpanan } \\
\text { obat tidak } \\
\text { dipergunakan } \\
\text { untuk } \\
\text { penyimpanan } \\
\text { barang lain. }\end{array}$ & $100 \%$ \\
\hline 5. & $\begin{array}{l}\text { Sistem } \\
\text { penyimpanan } \\
\text { berdasarkan } \\
\text { bentuk sediaan. }\end{array}$ & $100 \%$ \\
\hline 6. & $\begin{array}{l}\text { Sistem } \\
\text { penyimpanan } \\
\text { berdasarkan } \\
\text { kelas terapi. }\end{array}$ & $100 \%$ \\
\hline 7. & $\begin{array}{l}\text { Sistem } \\
\text { penyimpanan } \\
\text { disusun secara } \\
\text { alfabetis. }\end{array}$ & $100 \%$ \\
\hline 8. & $\begin{array}{l}\text { Pengeluaran obat } \\
\text { memakai sistem } \\
\text { FIFO. }\end{array}$ & $100 \%$ \\
\hline 9. & $\begin{array}{l}\text { Pengeluaran obat } \\
\text { memakai sistem } \\
\text { FEFO. }\end{array}$ & $100 \%$ \\
\hline 10. & $\begin{array}{l}\text { Ruang } \\
\text { penyimpanan } \\
\text { memperpafikan } \\
\text { kondisi sanitasi, } \\
\text { temperatur, } \\
\text { kelembaban, } \\
\text { adanya ventilasi } \\
\text { serta pemisahan. }\end{array}$ & $100 \%$ \\
\hline
\end{tabular}




$\begin{array}{ll}\text { 11. } & \begin{array}{l}\text { Ruang } \\ \text { penyimpanan } \\ \text { dilengkapi } \\ \text { dengan rak/ } \\ \text { lemari obat, } \\ \text { pallet, pendingin } \\ \text { ruang (AC), } \\ \text { lemari } \\ \text { pendingin. }\end{array} \\ \text { 12. } & \begin{array}{l}\text { Tersedianya } \\ \text { lemari khusus } \\ \text { penyimpanan } \\ \text { narkotika dan } \\ \text { psikotropika. } \\ \text { Tersedianya } \\ \text { kartu stok obat } \\ \text { pada setiap obat } \\ \text { dalam rak/lemari } \\ \text { penyimpanan. } \\ \text { Tersedianya } \\ \text { kartu suhu dan } \\ \text { alat pengukur } \\ \text { suhu dalam } \\ \text { ruang } \\ \text { penyimpanan. } \\ \text { Ruang arsip } \\ \text { dalam }\end{array} \\ \text { 13. } 100 \% \\ \text { 15. } 100 \% \\ \end{array}$

a. Obat/bahan obat disimpan di dalam wadah asli dari pabrik.

Pada penelitian ini dilakukan pengamatan terhadap 10 macam kelas terapi obat yaitu vitamin dan suplemen; antiinfeksi dan saluran kemih; antialergi dan kortikosteroid; saluran pencernaan; saluran pernafasan; antihipertensi dan antikolesterol; anti asam urat; analgesik dan sistem saraf pusat; antidiabetik; serta psikotropika dan narkotika, dengan mengamati 3 macam obat dari masing-masing kelas terapi obat tersebut. Teknik pengamatan ini dilakukan dengan cara simple random sampling.

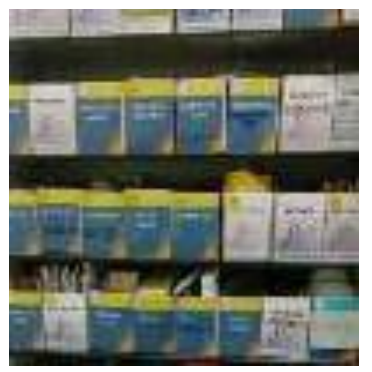

Gambar 1. Contoh obat yang disimpan di dalam wadah asli.

Hasil analisis data menunjukkan bahwa seluruh obat disimpan di dalam wadah asli dari pabrik

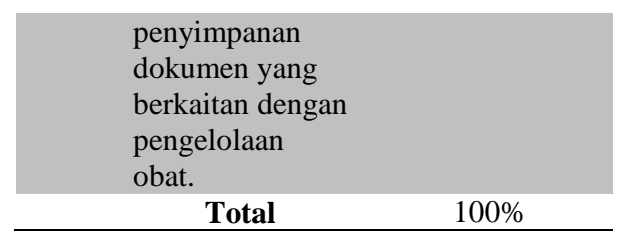

Berdasarkan pada hasil observasi yang dilakukan, implementasi penyimpanan obat di Apotek Kimia Farma GKB menunjukkan nilai persentase $100 \%$ untuk kategori yang tergolong dalam rentang "Sangat Baik" (81-100\%). Hal ini menunjukkan bahwa Apotek Kimia Farma GKB telah memenuhi standar penyimpanan obat berdasarkan Permenkes RI Nomor 73 Tahun 2016 tentang Standar Pelayanan Kefarmasian di Apotek.

(100\%), sebagaimana ditunjukkan pada Gambar 1. Hasil wawancara dengan apoteker menunjukkan bahwa setiap petugas farmasi yang akan melakukan penyimpanan obat diarahkan oleh Apoteker untuk menata obat sesuai dengan SOP.

b. Tersedia informasi yang tertulis secara jelas pada obat, apabila obat tersebut dipindahkan ke dalam wadah baru.

Untuk menguji variabel ini, digunakan teknik simple random sampling. Hasil analisis data menunjukkan bahwa informasi telah tertulis secara jelas (100\%) apabila obat dipindahkan ke dalam wadah baru (Gambar 2). Berdasarkan pada hasil wawancara dengan apoteker, terbukti bahwa setiap petugas farmasi yang akan melakukan penyimpanan obat telah diarahkan oleh Apoteker untuk menyimpan obat tersebut sesuai dengan SOP. 


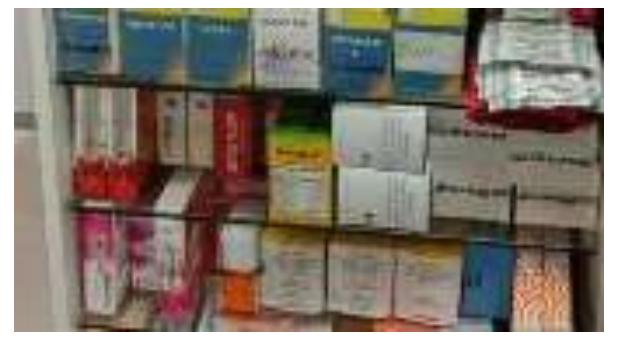

Gambar 2. Contoh obat yang disimpan di dalam wadah baru.

\section{c. Obat disimpan pada kondisi penyimpanan} sebagaimana tercantum dalam kemasan.

Variabel ini diamati dengan menggunakan teknik simple random sampling. Hasil analisis data menunjukkan bahwa semua obat (100\%) telah disimpan pada kondisi penyimpanan yang sesuai dengan informasi yang tercantum pada kemasan (Gambar 3). Berdasarkan pada hasil wawancara dengan apoteker, ditemukan fakta bahwa setiap petugas farmasi yang akan melakukan penyimpanan obat telah diarahkan oleh apoteker untuk menyimpan obat sesuai dengan SOP (Gambar 3).

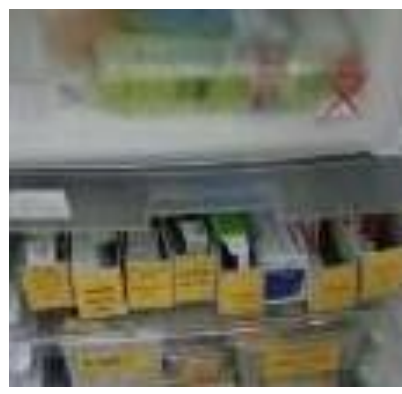

Gambar 3. Contoh obat yang disimpan pada kondisi penyimpanan yang sesuai dengan informasi yang tertera pada kemasan obat.

\section{d. Tempat penyimpanan obat tidak} dipergunakan untuk penyimpanan barang lain.

Teknik pemilihan sampel yang digunakan pada variabel ini adalah purposive sampling. Hasil analisis data menunjukkan bahwa tempat penyimpanan obat tidak dipergunakan untuk penyimpanan barang lain (100\%), seperti terlihat pada Gambar 4. Berdasarkan pada hasil wawancara, ditemukan bahwa setiap petugas farmasi yang akan melakukan penyimpanan obat telah diarahkan oleh Apoteker untuk menyimpan obat sesuai dengan SOP.

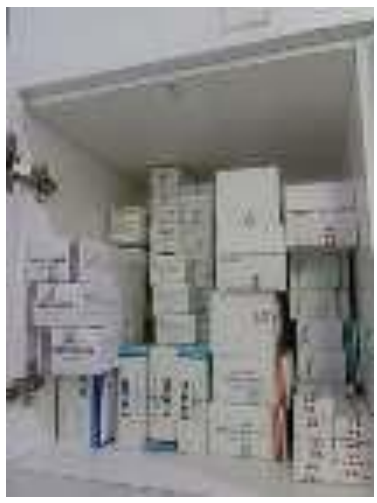

Gambar 4. Contoh tempat penyimpanan obat.

\section{e. Sistem penyimpanan obat berdasarkan pada} bentuk sediaan.

Teknik pengambilan sampel yang digunakan pada penentuan variabel ini adalah purposive sampling. Hasil analisis data menunjukkan bahwa sistem penyimpanan obat telah dilaksanakan berdasarkan pada bentuk sediaannya (100\%). Berdasarkan pada hasil wawancara dengan apoteker, diketahui bahwa setiap petugas farmasi yang akan melakukan penyimpanan obat telah diarahkan oleh Apoteker untuk menyimpan obat sesuai dengan SOP (Gambar 5).

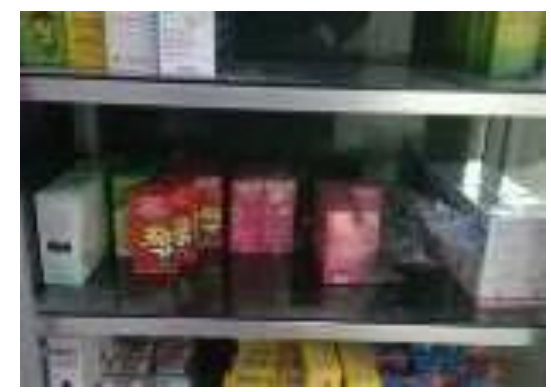

Gambar 5. Contoh Penyimpanan obat berdasarkan pada bentuk sediaannya 


\section{f. Sistem penyimpanan obat berdasarkan pada kelas terapi obat.}

Pengamatan variabel ini dilakukan dengan menggunakan teknik simple random sampling. Hasil analisis data menunjukkan bahwa sistem penyimpanan obat telah dilakukan berdasarkan pada kelas terapi obat (100\%). Berdasarkan pada hasil wawancara dengan apoteker, ditemukan bahwa setiap petugas farmasi yang akan melakukan penyimpanan obat telah diarahkan oleh apoteker untuk menyimpan obat sesuai dengan SOP (Gambar 6).

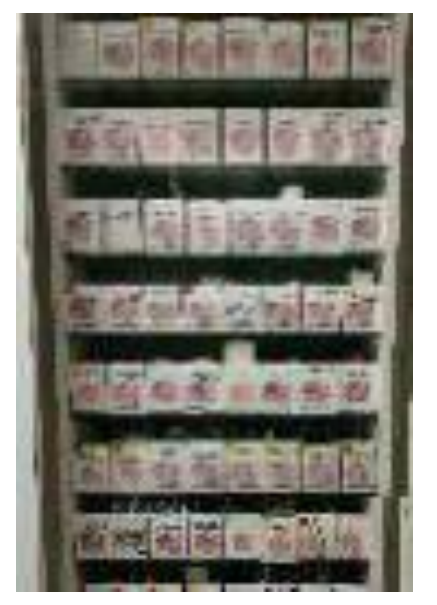

Gambar 6. Penyimpanan obat berdasarkan pada kelas terapinya.

\section{g. Sistem penyimpanan obat yang disusun secara alfabetis.}

Pengamatan variabel ini dilakukan pada sampel yang dipilih dengan menggunakan teknik simple random sampling. Hasil analisis data menunjukkan bahwa sistem penyimpanan obat di Apotek Kimia Farma GKB telah disusun secara alfabetis (100\%). Berdasarkan pada hasil wawancara, terbukti bahwa apoteker telah mengarahkan petugas untuk menyimpan obat sesuai dengan urutan alfabetis (Gambar 7). Sistem penataan ini diberlakukan untuk penyimpanan setiap obat pada rak/gondola, yang disusun mulai dari konsonan A di pojok atas sebelah kiri lalu berjajar ke samping hingga ke bawah secara berurutan dengan rapi seperti yang ditunjukkan oleh Gambar 7. Berdasarkan pada hasil wawancara terbukti bahwa Apoteker tetap memberikan arahan terkait tindakan double check yang perlu dilakukan pada saat melakukan penyimpanan maupun pengeluaran obat dari rak/ lemari penyimpanan.
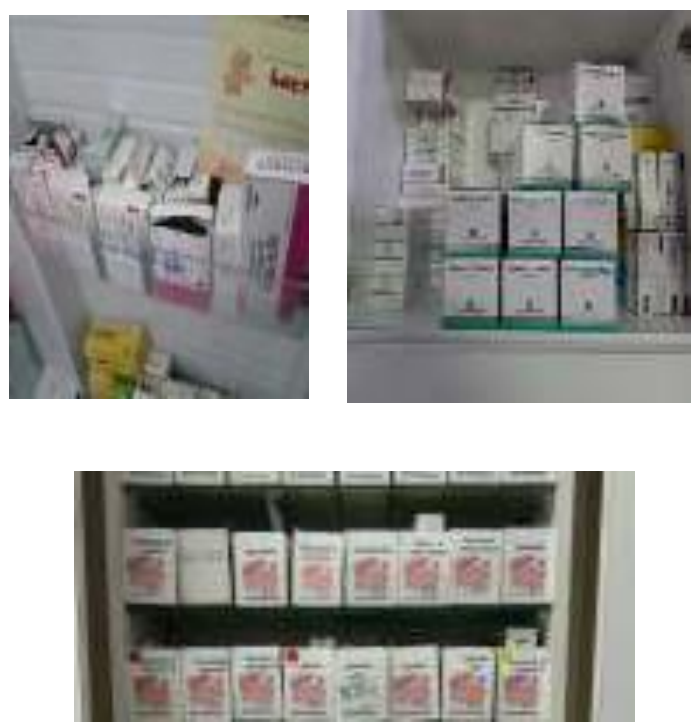

Gambar 7. Penyimpanan obat berdasarkan pada urutan alfabetis.

\section{h. Pengeluaran obat yang menerapkan sistem FIFO.}

Teknik pengambilan sampel yang digunakan pada variabel ini adalah purposive sampling. Hasil analisis data menunjukkan bahwa petugas telah melakukan pengeluaran obat dari tempat penyimpanan dengan menerapkan sistem FIFO (100\%). Berdasarkan pada hasil wawancara dengan apoteker, sistem pengeluaran obat/produk di Apotek Kimia Farma GKB telah menerapkan sistem double check terhadap identitas obat, yaitu tanggal penerimaan dan nomor bets pada kartu stok. Hal ini dapat meningkatkan kewaspadaan dalam upaya 
pemantauan obat sehingga stok obat tetap terjaga. Obat disimpan sesuai dengan urutan kedatangan di mana obat yang pertama kali datang akan diletakkan pada bagian depan rak sehingga obat dapat dikeluarkan lebih awal.

\section{i. Pengeluaran obat yang menggunakan sistem FEFO.}

Variabel ini diuji dengan menggunakan teknik pengambilan sampel secara purposive sampling. Hasil analisis data menunjukkan bahwa petugas telah melakukan pengeluaran obat dari tempat penyimpanan dengan menerapkan sistem FEFO (100\%). Berdasarkankan pada hasil wawancara dengan apoteker, sistem pengeluaran obat/produk di Apotek Kimia Farma GKB telah menerapkan sistem double check terhadap identitas obat, yaitu expiry date yang lebih dekat harus dikeluarkan terlebih dahulu. Hal ini dapat meningkatkan kewaspadaan dalam upaya pemantauan terhadap tanggal kadaluarsa dan stok obat tetap terjaga. Obat telah disusun sesuai dengan urutan batas tanggal kadaluarsa. Obat dengan batas tanggal kadaluarsa (Expiry Date) yang lebih dekat telah ditempatkan pada bagian depan rak tempat penyimpanan obat, sedangkan obat dengan batas tanggal kadaluarsa yang lebih lama ditempatkan di belakangnya. Berikut ini merupakan faktor yang dapat menyebabkan terjadinya obat kadaluarsa, yaitu ketidaktepatan dalam perencanaan obat, permasalahan kualitas obat, dan proses pengelolaan penyimpanan obat yang tidak sesuai standar (Akbar, dkk., 2016).

\section{j. Ruang penyimpanan obat dengan memperhatikan kondisi sanitasi, temperatur, kelembaban, ketersediaan ventilasi, serta pemisahan.}

Teknik yang digunakan pada pengujian variabel ini merupakan purposive sampling. Hasil analisis data menunjukkan bahwa ruang penyimpanan obat telah memperhatikan kondisi sanitasi, temperatur, kelembaban, ketersediaan ventilasi, serta pemisahan (100\%). Berdasarkan pada hasil wawancara dengan apoteker, ditemukan bahwa setiap petugas farmasi yang akan melakukan penyimpanan obat telah diarahkan oleh apoteker untuk menjamin bahwa penyimpanan obat telah dilaksanakan sesuai dengan SOP.

\section{k. Ruang penyimpanan dilengkapi dengan rak/lemari obat, pallet, pendingin ruang (AC), lemari pendingin.}

Pengujian variabel ini dilakukan dengan menggunakan teknik pengambilan sampel yaitu purposive sampling. Hasil analisis data menunjukkan bahwa ruang penyimpanan obat telah dilengkapi dengan rak/lemari obat, pallet, pendingin ruang (AC), lemari pendingin (100\%). Berdasarkan pada hasil wawancara dengan apoteker, ditemukan bahwa setiap petugas farmasi yang akan melakukan penyimpanan obat telah diarahkan oleh Apoteker sehingga penyimpanan obat yang dilaksanakan sesuai dengan SOP. Obat telah disimpan pada tempatnya masing-masing sebagai jaminan akan keamanan penyimpanan obat. Selain itu hal ini dapat memudahkan petugas untuk melakukan pengambilan serta penyimpanan obat.

\section{Tersedianya lemari khusus penyimpanan narkotika dan psikotropika.}

Teknik pengambilan sampel yang digunakan untuk menguji variabel ini adalah purposive sampling. Hasil analisis data menunjukkan bahwa tersedia lemari khusus sebagai tempat penyimpanan narkotika dan psikotropika (100\%), seperti ditunjukkan pada Gambar 8. Berdasarkan pada hasil wawancara dengan apoteker, ditemukan bahwa setiap petugas farmasi yang akan 
melakukan penyimpanan obat di dalam lemari psikotropika dan narkotika telah diarahkan oleh apoteker, sesuai dengan SOP.

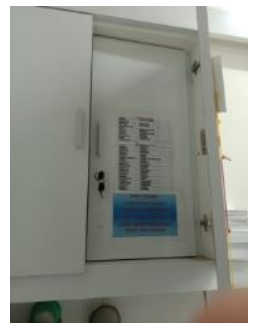

Gambar 8. Lemari khusus obat psikotropika dan narkotika.

\section{m. Tersedianya kartu stok obat.}

Teknik pengamatan yang diterapkan pada uji variabel ini adalah simple random sampling. Hasil analisis data menunjukkan bahwa sistem penyimpanan obat di Apotek Kimia Farma GKB telah dilengkapi dengan kartu stok obat untuk setiap obat (100\%) yang diletakkan di dalam rak/lemari penyimpanan, seperti terlihat pada Gambar 9. Berdasarkan pada hasil wawancara, terbukti bahwa setiap petugas farmasi yang akan menyimpan obat dalam rak/lemari diarahkan oleh Apoteker sehingga penyimpanan obat yang dilakukan telah sesuai dengan SOP.

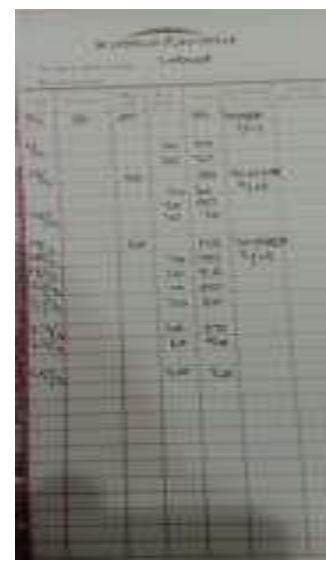

Gambar 9. Kartu stok obat.

\section{n. Tersedianya kartu suhu dan alat pengukur suhu.}

Teknik pengambilan sampel yang digunakan pada pengujian variabel ini adalah purposive sampling. Hasil analisis data menunjukkan bahwa ruang penyimpanan obat telah dilengkapi dengan kartu suhu dan alat pengukur suhu (100\%). Berdasarkan pada hasil wawancara dengan apoteker, terbukti bahwa setiap petugas farmasi yang akan melakukan penyimpanan obat telah diarahkan oleh apoteker untuk menyimpan obat sesuai dengan SOP (Gambar 10). Berdasarkan pada hasil pengamatan, persentase kelembaban tercatat sebesar 51-52\% di dalam ruang penyimpanan obat. Persentase kelembaban yang baik di dalam ruang penyimpanan obat menurut Shafaat, dkk. (2013) adalah kurang dari $60 \%$. Dengan demikian kelembaban di dalam ruang penyimpanan obat di Apotek Kimia Farma sudah memenuhi persyaratan.

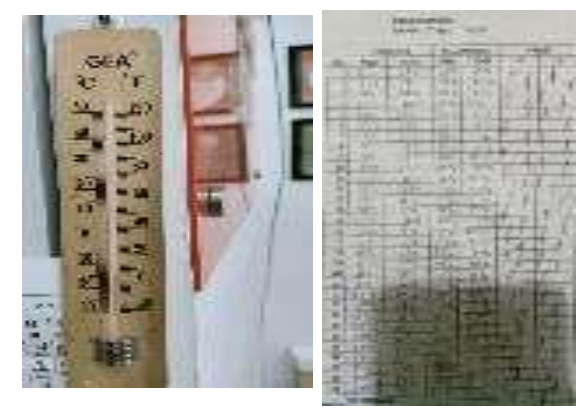

Gambar 10. Kartu suhu dan thermometer di dalam ruang penyimpanan obat.

\section{o. Ruang arsip untuk penyimpanan dokumen.}

Teknik pengambilan sampel yang digunakan pada pengujian variabel ini adalah purposive sampling. Hasil analisis data menunjukkan bahwa ruang arsip untuk penyimpanan dokumen yang berkaitan dengan pengelolaan obat dinilai baik $(100 \%)$. Berdasarkan pada hasil wawancara, terbukti bahwa ruang arsip hanya digunakan untuk penyimpanan dokumen atau barang tertentu. Ruang arsip juga berfungsi sebagai ruang 
-Ade Seldiano-Sistem Penyimpanan Obat di Apotek Kimia Farma GKB- Halanan 22-30

penyimpanan dokumen penting yang terkait dengan pengelolaan apotek.

\section{KESIMPULAN}

Berdasarkan hasil penelitian ini, disimpulkan bahwa evaluasi dari sistem penyimpanan obat di Apotek Kimia Farma GKB telah sesuai dengan ketentuan yang diatur di dalam Peraturan Menteri Kesehatan Nomor 73 Tahun 2016 tentang Standar Pelayanan Kefarmasian di Apotek, y a i t u $100 \%$ pada kategori "Sangat Baik" (81-100\%).

\section{UCAPAN TERIMAKASIH}

Penulis ingin mengucapkan terimakasih kepada Apotek Kimia Farma GKB, Universitas Muhammadiyah Gresik, serta semua pihak yang telah memberikan banyak dukungan sehingga penelitian ini dapat terselesaikan dengan baik dan lancar.

\section{DAFTAR PUSTAKA}

[1] Akbar, N.H., Kartimah, N., Wijaya, C. 2016. Analisis Manajemen Penyimpanan Obat di Puskesmas se-Kota Banjarbaru. Jurnal Manajemen dan Pelayanan Farmasi. Vol. 6, No. 4., hlm: 255-260.

[2] Ardiningtyas, B. dan Dwi, S. 2019. Gambaran Penyebab dan Kerugian karena Obat Rusak dan Kedaluarsa di Apotek Wilayah Kota Yogyakarta. Laporan Penelitian. Fakultas Farmasi. Universitas Gadjah Mada. Yogyakarata.

[3] Asyikin, A. 2018. Studi Implementasi Sistem Penyimpanan Obat Berdasarkan Standar Pelayanan Kefarmasian di Apotek Sejati Farma Makassar. Jurnal Media Farmasi. Vol. XIV, No. 1, hlm: 29-34.

[4] Karlida dan Ida, M. 2017. Suhu Penyimpanan Bahan Baku dan Produk Farmasi di Gudang
Industri Farmasi. Jurnal Farmaka. Vol. 15, No. 4, hlm: 58-67.

[5] Menteri Kesehatan Republik Indonesia. 2016. Peraturan Menteri Kesehatan Republik Indonesia Nomor 73 Tahun 2016 tentang Standar Pelayanan Kefarmasian di Apotek.

Jakarta: Kementerian Kesehatan Republik Indonesia.

[6] Presiden RI. 2009. Peraturan Pemerintah Republik Indonesia Nomor 51 Tahun 2009 tentang Pekerjaan Kefarmasian. Jakarta: Pemerintah Presiden Republik Indonesia.

[7] Shafaat, K., Afzal, H., Brajesh, K. 2013. Storage of Pharmaceutical Products. World Journal of Pharmacy and Pharmaceutical Sciences. Vol. 2 